\title{
Depression and Suicide in "All the Bright Places" by Jennifer Niven and "My Heart and Other Black Holes" by Jasmine Warga: \\ A Cognitive reading*
}

Dina Mostafa Ahmed*

dinamostafa22@hotmail.com

keywords: Depression - Suicide - All the Bright Places Jennifer Niven - My Heart - Jasmine Warga.

This thesis is a study of Cognitive theory of depression and suicide as represented in All The Bright Places by Jennifer Niven and My Hear And Other Black Holes by Jasmine Warga. Cognitive psychology is the field of psychology that focuses on the internal mental processes; these mental processes are centered on gaining knowledge and comprehension. They include perception, memory, creativity, language, problem solving, attention, and thinking. ${ }^{1}$

* Thesis (M.A.), Faculty of Education, Department of Curriculum \& Instruction, Ain Shams university.

${ }^{*}$ Lecturer Assistant of the English Language Department, University Requirement Unit, Misr University for Science \& Technology.

1) McLeod, Saul. Psychological Theory of Depression, 2015. (https://www.simplypsychology.org/depression.html) 
This cognitive theory is applied on two works of art All the Bright Places (2015) by Jennifer Niven and My Hearts and Other Black Holes (2015) by Jasmine Warga. The aim of the study is to determine the influence of family and society on children and how the cognitive theory of depression interprets it.

Chapter one discusses the theory of Albert Ellis, Aaron T Beck, and Martin Seligman. Albert Ellis (1913-2007) is an American psychologist and one of the originators of the cognitive theory and is the founder of Cognitive-Behavioral Therapies (CBT). Ellis developed the ABC model of depression which explains the individual's post-trauma thinking and behavior. He proposed that this sequence of stages is triggered through a chain of developments which start from receiving the negative event to the culmination of the subsequent reactions following the trauma; this may lead the individual to depression.

Aaron T. Beck (1921-) is an American psychologist and the father of cognitive therapy. He examines the effect of any negative event or a trauma on the individual leading him to depression and suicide. Beck asserts that the individual is prone to depression after a sequence of negative events; these events effect the individual's life and perspective which in turn effect his behavior. Finally, the theory of Learned Helplessness was created by Martin Seligman (1942- ). He is an American psychologist; he proposed a cognitive explanation of depression called Learned Helplessness. He proved his theory by an experiment made on dogs and how they become helpless and passive after being exposed to 
several electric shocks. Later, it is applied on human; after experiencing many events, the individual feels helpless and useless and then he becomes passive.

Chapter two is the application of the theories of Ellis, Beck and Seligman on the characters of the work of art All the Bright Places. The theory explains the reasons that led them to be depressed and its impact on their psychological formulation. It also tackles the aetiology of being suicidal or having suicidal ideation.

Chapter three is also an application of the theory of Ellis, Beck and Seligman on My Heart and Other Black Holes by Jasmin Warga. It argues that depression is a consequence of many aspects and it may be a result of an irrational thinking. In addition, in this chapter the role of the family and society is underscored as a vital factor in the process of traumatization.

The thesis argues that not only the occurrence of a trauma or negative events lead to depression and suicidal ideation but also the environment, family and society, are among the major causes of this depression. In addition these traumatic development could be escaped and healed through a chain of cognitive therapies that subsume change of perspectives, disclosure, etc.. 
الاكتئاب والنزعة الانتحاريـة في "كل الأماكن المشرقة"

لـ"جنيفر نيفن" و"قلبي والثقوب السوداء " لـ"جاسمين وارجا":

قراءة في ضوع علم النفس المعرفي

دينا مصطفى أحمد

موضوع الاراسة:

تهدف هذه الدراسة الى تبين مدى تأثير نظريـة السلوك المعرفي للاكتئاب والنزعـة الانتحاريـة على روايـة "كل الأمـاكن المشـرقة" لـ"جينيفر نيفن" و "قلبـي والثقوب السوداء" لـ"جاسمين راجـا". تتناول هذه الدراسـة الميكنات المسئولة عن الاكتئاب والتي هي فقدان المري لثخص مـا وفقدان الثقـة في النفس والثـعور بالعجز وكل ذلك يشكل حافزًا كبيرًا للتفكير في الانتحار أو محاولة الانتحار والذي هو نتيجة طبيعيـة للاكتئاب. عـلاوة على ذلك يتناول هذا البحث كيف يتعامل أو يتجاهل المجتمع المضطربين نفسيَّا، وكيف يتعاملون مـع فكرة موت شخص منتحرًا. فإن النزعـة الانتحاريـة والاكتئاب لا يتم التعامل معها كمشكلة كبيرة حقيقية وهامة تهدد حياة المراهقين والشباب، بل يتم تجاهلها تمامًا وكثيرًا ما يتجاهلها المجتمـع لأن المجتمع يخثى مناقثـة هذه المشـاكل والتي هي بالتالي تعرض حياة الكثيرين إلى الاكتئاب المزمن أو التفكير في الانتحار ، إضافة إلى ذلك تركز الدراسة على النبذ الإجتماعي الذي يتعرض اليه الكثير من المراهقين والثباب. 
فهذا النبـذ الاجتمـاعي يلعـب دورًا هامَّا في تثكيل وزيـادة الاكتئـاب لدى المراهقين والثباب. هنا تقوم نيفن بإلقاء الضوء على دور ومدى تأثير العائلة على المراهقين سواء بالإيجاب أو بالسلب وكيف أن بإمكانها أن تدمر حياتهم. فالعائلة تلعب دورًا هامَّا في حماية أبنائها من أي اضطرابات أو عوامل خارجية يمكنها التأثير على نفسية وحياة أفراد هذه العائلة. فإذا كانت العائلة متماسكة ومتفاهمة فيمكنها التكفل بحماية وإنقاذ أبنائها من التعرض لأي مرض نفسي واذا تعرض أحد الأفراد لأي ضرر ستساعده على التعافي منهه، على عكس الكثير من العائلات التي لا تعير إفرادها أي اهتمام لأسباب خارجية أو داخلية مثل الانشغال بالعمل لتوفير القوت اليومي أو بسبب مشاكل عائلية مثل الطلاق أو العنف الأسـري. كل ذلك يسبب الاكتئـاب والاضـطراب النفسي للمـره خاصَّـا المراهقين. 